\title{
Understanding underutilisation of locally grown tropical fruit and vegetables - why are imported apples preferred in Malaysia?
}

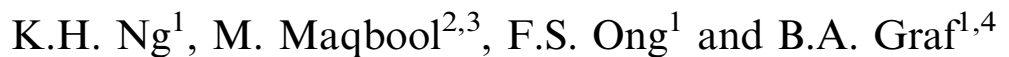 \\ ${ }^{1}$ University of Nottingham Malaysia Campus, Semenyih, Selangor, Malaysia, \\ ${ }^{2}$ Crops for the Future Research Centre, Semenyih, Selangor, Malaysia, \\ ${ }^{3}$ Department of Horticulture, The University of Poonch, Pakistan and \\ ${ }^{4}$ Department of Health Professions, Manchester Metropolitan University, M15 6BG Manchester, UK
}

South East Asia is one of the most biodiverse regions on this planet and $>370$ tropical fruits and $>100$ tropical vegetables have been found in Malaysia ${ }^{(1)}$. Pilot data suggests however, that Malaysian consumers prefer to purchase imported fruit and vegetables $(\mathrm{F} \& \mathrm{~V})^{(2,3)}$. By exploring consumers purchasing behaviour in Kajang, a suburban area near Kuala Lumpur, this study aimed to generate hypothesises to understand underutilisation of locally grown tropical crops.

Purchase frequency of 15 locally grown tropical crops (dragon fruit, durian, jackfruit, kedondong, kuini, mangosteen, peria pantai, petai, pink guava, pomela, salak, salam, star fruit, soursop, water apple) and 5 globally available crops (apple, banana, cauliflower, okra, orange) was examined via an online questionnaire (Qualtrix). In addition, place of purchase of each crop, reasons for not purchasing each crop, general eating patterns, and motivation for buying F\&V were recorded. The questionnaire was distributed using social media, and 84/167 responses were complete. All respondents were resident in Malaysia for $\geq 2$ years and a main purchaser of foods in their household.

$96 \%$ of respondents said that they consume $\geq 1$ portion of $\mathrm{F} \& \mathrm{~V}$ per day (more specifically, $4 \%, 26 \%, 29 \%, 25 \%$ and $4.3 \%$ of respondents said they consume $0,1,2,3 \geq 4$ portions/day). On a Likert scale ( $1=$ strongly disagree and $5=$ strongly agree), healthy eating scored $4.36 \pm 0.67$ (mean \pm SD). When asked "why do you buy F\&V?", the two highest scoring answers (out of 10) were "because F\&V are healthy" $4.07 \pm 0.91$ and "because we like the taste" $4.14 \pm 0.88$.

Apples were scored as the most frequently purchased crop, with a mean of $4.01 \pm 1.07$ (SD) (on a 5 point Likert scale where $1=$ never, $2=$ rarely, $3=$ sometimes, $4=$ often and $5=$ all the time $)$. Purchase frequency for 9 locally grown tropical crops $(k e d o n d o n g$, kuini, peria pantai, petai, pink guava, pomela, salak, salam and soursop) was rated between 1 (never) and 2 (rarely). Only 6 locally grown tropical crops (dragon fruit, durian, jackfruit, mangosteen, star fruit and water apple) received ratings between 2 (rarely) and 3 (sometimes).

The most important reason for not buying kedondong, kuini, peria pantain, salak, and salam was a) lacking familiarity with these $\mathrm{F} \& \mathrm{~V}$ and/or no knowledge how to prepare/eat them, or b) not available when shopping. Dislike of taste, texture or smell were reasons for not buying durian, kedondong, peria pantai, petai, salak and soursop. "Too expensive" or "perishes quickly" was of no importance. Place of purchase for underutilised crops were 1) markets and roadside stalls, 2) local shops, but also 3) supermarkets. Place of purchase for globally available crops were mainly supermarkets, however local shops and markets were also listed.

In conclusion, respondents were aware of health benefits of $\mathrm{F} \& \mathrm{~V}$, however imported crops such as apples, oranges or cauliflower were preferred over locally grown tropical produce. Lack of familiarity with locally grown tropical crops was the main reason for not buying them. Thus, increasing public awareness of locally grown tropical crops may significantly promote the demand and consumption by the Malaysian public.

1. Shukri MA, Salma I, Mirfat A, and Shukor N (2009). Proc of National Conf. on New Crops \& Bio-Resources.

2. Izzah N, Aminah A, Pauzi A et al. (2012) Intl. Food Research Journal 19(3): 1095-1107.

3. Khairunnisa I, Shahrim A, Roselina K et al. (2012) Journal of Agribusiness Marketing 5, 29-46. 